\author{
Марина С. ЈАњИЋ ${ }^{*}$ \\ Универзитет у Нишу \\ Филозофски факултет \\ Департман за српски језик
}

\title{
ТЕМЕЉНА МЕТОДОЛОШКА ПИТАҢА НАСТАВЕ СРПСКОГ ЈЕЗИКА У ДИЈАСПОРИ
}

\begin{abstract}
Услед појачаних емиграционих процеса са подручја наше земље крајем прошлог и почетком овог века знатно је промењена демографска карта Србије. У условима када једна половина Срба живи у матици, а друга половина у дијаспори, веома је важно очувати национални идентитет и културну баштину међу нашим исељеницима и њиховим потомцима. Будући да кључ националног идентитета лежи у језику, последњих година искристалисала се јасна потреба за организацијом наставе српског језика у дијаспори. Ову нову лингвометодичку грану, с обзиром на специфичности њених циљева и задатака, карактеришу извесне методолошке посебности из којих произилазе поља рада, функционална поступања и организација наставних стратегија у креирању наставних интерпретација. Ова специјална методика представља огранак методике наставе српског као страног, будући да је ученицима из дијаспоре матерњи језик земље у којој су рођени. С обзиром на то да је њен примарни наставни принцип - принцип завичајности и да је утемељена на завичајној педагогији, један од најконструктивнијих предлога за именовање ове нове лингвометодичке дисциплине јесте методика наставе српског као завичајног.

Кључне речи: дијаспора, идентитет, националност, завичај, лингвометодика, језичке компетенције, комуникација, интеркултуралност, трансференција.
\end{abstract}

\section{Увод}

У условима учесталих светских миграционих кретања и стварања нових дијаспора, пажњу научне јавности заокупља појам националног идентитета, и то не само у друштвеним научним дисциплинама већ и у примењеној лингвистици. Кључно питање у вези са дијаспором јесте критеријум за одређење националног идентитета: да ли је то место рођења, боравка, држављанство, припадност фамилији и емоционална спрега са родбином или пак прагаматичка веза са неком друштвеном заједницом из материјалне користи, интереса или принуде?! Овај последњи

*marina.janjic@filfak.ni.ac.rs 
критеријум обележава савремено светско друштво у глобалистичком кретању те је евидентно стварање сложених мрежа фрагментарних и флуидних идентитета ${ }^{1}$, под којим се подразумева вештачка, интересна прагматичка националност адаптибилна задатим околностима. „Ипак, овај теоријски концепт не искључује ирационалну и емотивну компоненту националног идентитета" (Milošević Đorđević 2003: 129-130) тако да и новопечене националне групе могу имати јаке емоције према своме пореклу и примордијалној националности. У таквим сложеним социјалним и психолошким дијаспорним околностима јавља се и потреба за додатним учењем завичајног језика. Управо је то и кључна тачка за наше истраживање: улога и значај националног идентитета унутар примењене лингвистике, а у вези с тим намећу се и питања завичајног (наследног, родног, предачког) језика и завичајних говорника. Језик је семиотички систем, а идентитет је семиотички потенцијал, тако да постоји јака спрега између националног идентитета и језика².

Питање националног идентитета унутар примењене лингвистике (наставе српског као завичајног) представља широко постулирани појам којим се обухватају вредносни системи, симболи и материјалне одреднице српског националног идентитета. Његова одређења подразумевају територију и државне границе државе Србије (географски положај), националну историју, фолклор и традицију (митови, легенде, обичаји и веровања у Срба), затим религију и културу (уметничко стваралаштво и научна достигнућа, али и спортски успеси у различитим дисциплинама). Ово је важно полазиште јер ће се у средишту наставе српског језика у дијаспори врло често наћи управо теме српске националне културе (етнички, географски, историјски, културни и језички идентитет). Дакле, у контексту етничког идентитета може се говорити о словенском (пра)пореклу Срба, прадомовини, кретањима у простору и времену, затим о пореклу самог етничког назива Словена, као и о важним историјским догађајима и слободарској непокорној српској традицији, о српским владарима (кнежевима и краљевима) и витезовима. Треба указати на државна знамења Србије: грб, заставу и химну. Културни иденитет обухватиће српске научне и уметничке ствараоце, знамените личности и културна добра; традиционалне игре, етномузику, традиционална кухиња, религија и српски свеци. Ту су свакако и спортисти који су освајали шампионате широм света. Када је реч о језичком идентитету, ваља истаћи да се народ често поистовећује са језиком и да је у језичким слојевима похрањена свеколика култура једног народа. Српски језик имао је свој специфични историјски развитак, кодификацију, своја писма - ћирилицу и српску латиницу и за-

${ }^{1}$ У покушајима дефинисања идентитета јављају се два различита приступа и то: примордијализам и инструментализам.

„Примордијализам полази од начела да је национални идентитет фиксан и трајан, непроменљив у току живота. Он је чврста и основна, базична људска категорија, дата рођењем, везује људе прадедовским пореклом, обојен ирационалним, неизрецивим осећањима. Национална осећања нису везана за конкретне и рационалне чињенице, већ су независна од стварних односа и потреба појединаца. По инструменталистичком схватању национални идентитет је променљив, флуидан и везан за посебне околности. Људи ће наглашавати националну припадност искључиво у ситуацијама у којима им то може донети неку корист. Национална идентификација није фиксна и непроменљива, већ је променљива и флуидна” (Milošević Đorđević 2003: 129-130).

${ }^{2} \mathrm{O}$ питању језика као кључу националног идентитета опширније у поглављу: Границе нашег језика су границе нашег света (Јањић, Чутура 2012: 9-27). 
узима аутономно место међу осталим словенским језицима. Поседује широк спектар супстандардних варијетета, како дијалекте и локалне говоре, тако и социолекте. Србистика је утемељена бројним граматикама, језичким приручницима, речницима са којима би требало упознати завичајне говорнике.

\section{Лингвометодичка перспектива српског језика у иностранству}

Настава српског језика у дијаспори своју смисленост оправдава у учвршћивању и очувању српског националног идентитета међу српским исељеницима и њиховим потомцима. Њоме се подстиче и негује национална свест и етничка припадност матици Србији. Њен основни циљ јесте оспособити ученике пореклом из Србије за успешну (усмену и писмену) комуникацију на српском језику, док је очекивани исход ове наставе развој и унапређивање језичких компетенција у области српског језика и ширег српског културног наслеђа. Одређивање наставног циља и очекиваних исхода представља почетак у свакој озбиљнијој методичкој интерпретацији. Но, специфичност најпре социолингвистичког, а потом и самог наставног контекста у коме се организије и изводи настава српског језика у иностранству указује на различитост у лингвометодичком приступу овом наставном задатку у односу на наставу српског језика у домаћим школама. Уз веома важну констатацију да се ова специфична лингвометодичка дисциплина почела релативно касно развијати у нашој земљи, ${ }^{3}$ морамо закључити да њене кључне методолошке поставке још увек нису утемељене, баш као што је и сам назив ове дисциплине на нивоу усвајања. ${ }^{4}$ Претходна истраживања превасходно су се тицала проучавања карактеристика и начина употребе (усменог и писаног) српског језика у дијаспори (лингвистички аспект). Штавише, ова истраживања обележила су седамдесете и осамдесете године прошлога века и интердисциплинарног су карактера (српскохрватски језик у дијаспори истраживан је са лингвистичког, психолингвистичког, социолингвистичког и филолошког аспекта). Но, са распадом Југославије раних деведесетих, ова тема остала је на маргини српске лингвистичке мисли. Тек 2014. године организују се два округла стола, и то један лингвистички под називом: „Српска језичка дијаспора: одржавање језика и идентитета говорника у мигрантским условима”, а други ет-

\footnotetext{
${ }^{3}$ Средином XX века огроман број наших исељеника одлази је у иностранство, нарочито у земље немачког говорног подручја, у потрази за сигурнијом егзистенцијом. Њихов политизовани (еуфемистички) назив претходне СФРЈ био је „радници на привременом раду у иностранству”, док су се у колоквијалном говору чешће називали гастарбајтери (нем. Gastarbeiter), што у преводу са немачког буквално значи: „гостујући радници”. Такви „гости” који су дошли тражећи посао, врло су се ретко враћали својим домовима. Но, исељавање са наших простора је кулминирало 90-их година прошлога века услед ратног вихора који се распламсао на тлу некадашње Југославије. Захваљујући свему томе, данас ван матице живи око шест милиона Срба, исто колико живи и у самој матици.

${ }^{4}$ Евидентна је терминолошка неусклађеност када је реч о српском језику у дијаспори (којим се служе мигранти и њихови потомци) па се он у региону означава изузетно шаролико и то као: породични, предчки, мигрантски, дијаспорни, завичајни, наследни, заборављени, језик порекла, па чак као и матерњи. У англофоним земљама, где су започета прва истраживања о овој теми, (Америци, Канади, Аустралији) употребљавају следећи термини: наследни језик (heritage language), језик националне мањине (еng. minority language), предачки језик (ancestral language), родни језик (native language), etnički jezik (ethnic language), језик заједнице (community language), кућни језик (home language) итд. (Роdboj 2016: 206).
} 
нографски: „Научно истраживање миграција у Србији: проблеми и иницијативе” (Вучина Симовић, Јовановић: 584). ${ }^{5}$

Језиком исељеника и њиховим националним идентитетом бавили су се многи научници у свету (M. Polinsky, O. Kagan, G. Valdes, N. Van Deusen-Scholl, A. Kelleher, J. Fishman, G. Feuerverger...), док је у научним истраживањима у региону ова дисциплина исписала значајне странице у оквиру методике наставе хрватског као иног језика (Л. Цвикић, 3. Јеласка, Л. Канајет Шимић, М. Самарџија, Г. Хрџица, Д. Павличевић Франић...): ${ }^{6}$

„Предлаже се да се цијело подручје овладавања језиком подијели на изворнојезичност која укључује истраживања стјецања J1 (првога језика и материнскога као изворнога језика) и инојезичност која укључује истраживања подручје стјецања Ј2 (инога језика, тј. другога и странога). [...] 1. Страни језик прототипно језик који се не говори у околини гдје тко живи и дјелује. [...] Други је језик прототипно језик који се говори у околини гдје тко живи и дјелује” (Јеласка 2007: 86-88).

Специфичност наставе хрватског језика у иностранству истиче и Дуња Павличевић Франић указујући на разлике у настави другог језика Ј2 између хрватског као страног и хрватског као наследног.

„У контексту хрватске наставе у иноземству, инојезичност не значи учење потпуно странога језика, него насљеднога језика, тј. језика родитеља и предака, језика културнога и националнога идентитета. [...] Због свега наведенога, а у складу са социолингвистичким, психолингвистичким и лингводидактичким теоријама, насљедни се говорници издвајају у посебну скупину инојезичних ученика" (Дуња Павличевић Франић 2012: 182).

Дакле, питање наставе српског језика у дијаспори заиста се не може поистоветити са начином интерпретације граматичких јединица у домаћим школама, а тиме се не може ни изједначити са наставом српског као матерњег језика. У терминологији ове врсте наставе треба поћи од статуса српског језика међу самим српским исељеницима и његовим потомцима и нивоа владања српским језиком од стране исељеника и њихових потомака. У вишедеценијској пракси усталило се тзв. „правило треће генерације", која показује објективно неочекивано интересовање за учење завичајног језика (Boon, Polinsky 2015: 4). ${ }^{7}$ Неоспорно је да значајан број деце учи српски језик у породици и то у најранијем детињству као једини или други језик.

\footnotetext{
${ }^{5}$ Први је одржан је на Филолошко-уметничком факултету у Крагујевцу под окриљем научног скупа Српски језик, књижевност, уметност октобра 2014. године. Други округли сто приређен је у Етнографском институту САНУ у Београду децембра 2014. године.

${ }^{6} \mathrm{y}$ теорији усвајања језика у кроатистици су јасно разграничена изворнојезична од инојезичних истраживања (што се може јасно уочити у свим радовима горепоменутих аутора). Изворнојезична истраживања односе се на овладавање хрватским као „материнским” језиком, док се инојезична истраживања односе на овладавањем хрватским као страним и другим језиком (у терминологију је ушао стари словенски придев: ини са значењем: страни, други, остали, који у српском језику постао историзам, а користи се само као префиксоид у сложеницама: ино-: иностранство, инокореспондент, инокосан, инопартнер, иновалута...).

${ }^{7}$ „Наиме, прва генерација имиграната најчешће користи свој језик или је у њему и даље доминантна, док се код друге генерације, рођене у новој земљи, јавља асиметрична двојезичност у корист језика доминантног у говорникову окружењу. Трећа генерација, чији су дједови и баке изворни мигранти, углавном је једнојезична науштрб насљедног језика. Но, у трећој или каснијим генерацијама јавља се често жеља за учењем насљеднога језика, било само као резултат спомињања културе и наслијеђа у обитељи или знатижење и трагања за собом и својим коријенима, стога и те ученике или говорнике такођер можемо назвати насљеднима, иако припадају генерацији у којој је језични доказ повезаности с насљедном културом одавно нестао” (Подбој 2016: 206-207).
} 
Даља социјализација и похађање вртића и школа доводи до превладавања језика окружења и образовања. Наравно, морамо поћи од питања: Шта је њима матерњи језик? Који је њима први, а који други језик? Које су националности? Како год одговор гласио, свакодневна језичка пракса чини их компетентнијим говорницима официјалног језика државе у којој живе него српског. Све ово упућује на закључак да се настави српског у дијаспори мора приступити као специјалном огранку наставе српског као страног језика:

„У складу са сувременим теоријама усвајања језика ${ }^{8}$, те имајући на уму све наведено, учењу и поучавању хрватскога језика у иноземству ваља приступити као инојезичноме процесу у којему се хрватски третира као насљедни језик (L2). При овладавању насљедним језиком треба истакнути да се тај процес, према главнини својих обиљежја, разликује и од овладавања другим и од овладавања страним језиком" (Павличевић-Франић 2012: 183).

\section{Терминолошко одређење појма српског језика у дијаспори}

Питање лингвистичког идентитета српског језика у дијаспори носи његово терминолошко разрешење. У бројним научним истраживањима овог проблема, сусрећемо се са веома разноврсном терминологијом (о чему је већ било речи на почетку текста). Новим генерацијама наших исељеника објективно посматрано, српски језик није матерњи, а ни завичајни, јер су рођени и одрасли у другој домовини, која има свој национални језик и идентитет, а нису га могли ни наследити у правом смислу те речи. Објективно гледано, то јесте језик њихових предака. Но, како је српски национални иденитет у центру пажње ове методичке дисциплине и као такав даје пуни смисао учењу српског језика у дијаспори, у низу коришћених термина: наследни, предачки, заборављени, завичајни, породични, језик порекла, језик дијасnоре... сматрамо да би предност требало дати термину „завичајни” из простог разлога што национална идентификација са завичајем представља најважнији критеријум за избор овог термина. Додатно образложење овог предлога налазимо у методолошком концепту завичајне педагогије ${ }^{9}$, која као поддисциплина фигурира више од пола века на овим просторима. Завичајна педагогија је методолошки стурктурирана и теоријски је еквивалентна настави завичајног језика, а њено најважније обележје јесте примена принципа завичајности у наставном процесу. Још један аргумент у прилог овом избору јесте психолошке природе и тиче се дубинског емоционалног порива који српске (и остале) мигранте нагони повратку вредностима остављеног завичаја. И заиста, од свих актуелних назива најснажнију и најтоплију

${ }^{8}$ Теорија универзалне граматике (N. Chomsky, 1966,1989); Когнитивистичка теорија (D. I. Slobin i C. A. Ferguson, The Studies of Child Language Development, 1973); Теорија улазнога језика (K. Nelson, Structure and Strategy in Learning to Talk, 1973); Теорија семантичке и синтактичке вучнице (P. Smiley - J. Huttenlocher, Conceptual Development, Journal of Child Language 22, 1995); Психолингвистичке и социолингвистичке теорије (J. Piaget, The psychology of the child, 1969; H.G.Widdowson, Teaching language as communication, 2000); Теорија о усвајању семантичких црта (E.V. Clark, First Language Acquisition, 1981; Cognitive development and acquisition of language, 2003); Комуникацијско-функционалне теорије усвајања језика (D. Hymess, Etnografija komunikacije, 1984; A. Martinet, Osnove opće lingvistike, 1982; S.C. Levinson, Pragmatics, 1995; G. Yule, Pragmatics, 1998, The Study of Language, 2003).

${ }^{9}$ О завичајној педагогији опширније у: Јањић 2015, Peruško 1966, Rosandić 2006, Skok 1975... 
емоционалну конотацију упаво поседује термин „завичај”, који у себи обухвата сву снагу родољубља и националног идентитета.

Наравно, не може се пренебрегнути оправданост прихватања ни осталих термина, а међу њима је свакако најфреквентнији у употреби „наследни језик”, што га управо и директно препоручује за стручну употребу. Но, у циљу релаксације ове терминолошке неусклађености, у наставку рада служићемо се терминима завичајни говорник и завичајни језик (методика наставе српског као завичајног) будући да је најбогатија аргументација и најпозитивнија асоцијација везана управо за завичајну наставу.

\section{Специфичности наставе завичајног српског језика}

Српски као завичајни језик има посебан статус у социјалном окружењу исељеника и њихових потомака, а који га у односу на језик државе „домаћина” категоризује као: други, мањински, недовољно познати, хибридни или међујезик. Из оваквог статуса завичајног језика, проистичу полазишта у спецификацији његове наставне методологије:

- ученици српског језика као завичајног поседују неуједначена језичка предзнања; неки ученици уопште не владају српским језиком;

- ученик не влада основним сазнањима о националним вредностима матице;

- $\quad$ у говору дијаспоре долази до преплитања и интерполације завичајног (cpпског) и њиховог изворног језика, а тиме и до стварања језичке хибридизације - међујезика са елеметима два или више језика; то је преплитање по хоризонтали;

- говор ученика у дијаспори такође карактерише и преплитање различитих језичких варијетета српског језика: дијалекта, социолекта и стандардног језика; то је преплитање по вертикали;

- српски говорници у дијаспори, услед непознавања довољног броја српских речи, склони су стварању и употреби неологизама које самостално креирају како би изразили неку мисао за коју им недостаје српска реч;

- настава српског као завичајног се организује тек након што се уводним тестирањем утврди ниво познавања српског језика ${ }^{10}$ (тј. улазни језик, док је циљни језик ове наставе стандардни српски идиом).

Наведено указује да се ученици српског као завичајног не могу посматрати као хомогени комуникативни скуп који поседује уједначени ниво језичких компетенција српског језика, већ су то њихове индивидуане карактеристике, а владање српским језиком зависи од више фактора:

- $\quad$ да ли је и у којој мери негована комуникација на српском језику у породици или одређеном социјалном окружењу;

- $\quad$ ко представља угледни говорни модел (родитељ, учитељ, рођаци, пријатељи), односно, да ли су у комуникацији на српском језику били изложени супстандрадном и/или стандардном идиому;

\footnotetext{
${ }^{10}$ Тестирање се врши на основу дескриптора Заједничког европског језичког оквира.
} 
- $\quad$ да ли је био изложен образовном (културном) утицају, тј. да ли је ученик претходно похађао српске допунске школе, да ли је у породици негована језичка и шира српска култура;

- $\quad$ да ли се у дијаспорној породици прате електронски српски медији, односно, да ли је преко дигиталних друштвених мрежа (Фејсбук, Твитер...) успостављена веза са матицом;

- колико је ученик мотивисан за учење завичајног идиома, каква је социокултурна атомсфера у којој одраста, какво му је професионално усмерење, у којој мери постоји емоционална приврженост матици (рођацима и пријатељима из Србије);

- $\quad$ какве су личне карактеристике ученика: узраст, пол, когнитивни развој, интересовања.

До сада је више пута потврђена повезаност исељеника са матицом: „[...] многа истраживања у земљи и у иностранству указују на чињеницу да је дијаспора чврсто емотивно усмерена на матичну државу, посебно ако се са њом чвршће идентификује” (Бобић, Весковић Анђелковић 2016: 488). Чврста национална спрега између дијаспоре и Србије језику поверава јако важну ујединујућу улогу са аспекта националне припадности (тј. са аспекта идентификације са припадницима своје националности), али и дистинктивну улогу с друге стране са аспекта националних разлика у односу на припаднике других националности, што је у условим, глобалног мултикултурализма веома важан социјални аспект. Сам српски језик добија и образовну улогу јер његовим усавршавањем дијаспора стиче могућност упознавања са културном историјом Срба и њеним савременим актуелностима. Дакле, комуникативна, образовна и развојна улога српског језика представља окосницу мотивације за наставни рад са нашим завичајним говорницима у дијаспори.

\section{Развој језичких компетенција}

У фокусу наставе српског као завичајног налази се развој језичких компетенција и то:

- $\quad$ граматичке компетенције (граматичка правилност и структура српског језика);

- $\quad$ социолингвистичке компетенције (језичко прикладно понашање у складу са социокултурним миљеом, етикете и форме учтивог језичког понашања);

- дискурсивне компетенције (логичко закључивање и мисаоно повезивање - појмовна целовитост изражавања);

- $\quad$ стратешке компетенције (избор вербалних и невербалних стратегија за остваривање успешне комуникације и превазилажење евентуалних потешкоћа током комуницирања);

- $\quad$ комуникативне компетенције (функционална употреба језика; способност изражавања мисли и осећања писменим и усменим путем). ${ }^{11}$

\footnotetext{
${ }^{11}$ Опширније у: Јањић 2016.
} 
Језичке компетенције засноване су на језичким вештинама, а то су: слушање/ разумевање, читање, писање, говорење, па им је поверено централно место у оперативном делу часа (након уводне мотивације и емоционално-интелектуалне припреме за рад). Језичка вештина слушања и разумевања је посебно важна за ученике који српским језиком владају мало или нимало, па у почетној, тзв. тихој, фази учења српског језика најпре усвајају артикулациону базу српског језика (фонетски систем). Тада је јако важно изговарати речи спорим темпом уз понављања речи како би ученицима била омогућена максимална слушна перцепција. У овој фази учења, поред монолошке, изразито се примењује и демонстративна метода. ${ }^{12}$ Основни предуслов овладавања вештинама читања и писања јесте упознавање са српским писмима, ћирилицом и латиницом, што се у зависности од узраста ученика може обавити поступком групне обраде слова или комплексним поступком ${ }^{13}$ (специфичност букварске наставе лежи у фонетском за разлику од већине европских етимолошких писама). Најсложенија језичка активност јесте говор и он се усавршава низом методичких радњи на часу како би се ученик оспособио за говорну интеракцију. Важно је овде нагласити кључну разлику између наставе матерњег језика и наставе српског у дијаспори, а то је да наведене активности: слушање/разумевање, читање, писање и говор у настави матерњег језика представљају методичке радње (функционалне поступке), док у настави завичајног (страног) језика представљају очекивани исход часа - тј. језичке вештине којима треба овладати; дакле оно што је у матерњем језику средство (метода), у завичајном постаје наставни циљ!

Резултат тога и јесте да се у оперативном делу часа одређени текст на српском језику чита, преводи, уочавају се и објашњавају непознате речи, а потом се одговара на питања о тексту. Након тога се унутар текста уочава одређена граматичка категорија (нпр. глаголски облик или време) и објасни се како се гради и употребљава па се то увежбава до краја часа. Важно је нагласити још једну разлику између матерњег и завичајног језика, а то је да у процесу овладавања српским језиком у дијаспори нема еквиваленције између теоријског лингвистичког знања и комуникацијских вештина, тј. граматичке и комуникативне компетенције (ако је ученик научио граматику, не значи да уме да је примењује у говорној пракси и да може комуницирати без граматичких грешака).

Јасно је, дакле, да развој језичких вештина у настави српског завичајног језика нужно захтева посебан методолошки приступ другачији од традиционалне предавачке наставе и сувопарног граматизирања, а то је комуникацијски модел учења завичајног језика, будући да је језичко предзнање ученика у дијаспори најчешће на елементарном (или чак врло ниском) нивоу разговорног језика. Слушање, читање, писање и говор захтевају комуникацијски функционалан процес у усвајању завичај-

${ }^{12}$ Препоручује се употреба флеш картица са сличицама (показивање сличица прати изговор одговарајуће лексеме), како би ученик повезао реч са њеним значењем. Може се применити и метода тоталног физичког одговора ученика на постављени захтев наставника, како бисмо проверили да ли разуме оно што је чуо (нпр. на налог: „Отвори прозор” ученик устаје и отвара прозор). Ова метода може се организовати као игровна активност (наставник даје налоге а сви ученици извршавају - ко погреши испада из игре) нпр. устани-седи или певањем песме Кад си срећан уз демонстрирање покрета (удари длан о длан, пуцкетај прстима, лупи ногом о под, потапши колена...).

${ }^{13}$ Опширније о букварској настави видети у истоименом поглављу књиге Српски језик за ученике у дијаспори (Јањић 2015б: 37-45). 
ног језика па је сходно томе комуникативна метода доминантна на овим часовима. ${ }^{14}$ Стицање језичких компетенција у директној је спрези са темељима функционалне граматике и усвајањем употребног језичког знања. Такође, акценат на часу ставља се и на перманентно богаћење речника ученика и то не само квантитативно већ и квалитативно (полисемичност појединих лексема). Функционална граматика и језичке (пре свега комуникативне) компетенције у настави свој пуни дидактички оквир проналазе у примени ситуационе методике засноване на имплементирању свакодневних комуникативних ситуација из непосредног животног садржаја блиских ученику. Хуманистичка педагогија (која је утемељена у социјалној педагогији Лава Виготског) представља компатибилно наставно окружење изучавања језика помоћу комуникативног модела. Учење кроз игру, асоцијативним путем, амбијентално и витагено, а са акцентом на наставној интеракцији, подстаћи ће језичка постигућа ученика на часу на завидном нивоу. Кроз говорну акцију и граматички садржаји ће бити експлицирани на много пријемчивији и прихватљивији начин. Као битне карактеристике наставе српског завичајног језика издвајамо:

- $\quad$ комуникацијски (интерактивни) модел - активација језичких радионица (игре улога - сценска комуникација, језичке игре, креирање комуникативних ситуација, живи дијалог са наставником);

- $\quad$ појмовно-функционалан приступ језику - уместо граматизирања актуелизује се учење граматике кроз моделе језика у акцији (усвојени граматички садржаји стављају се у службу вербалног општења);

- $\quad$ хуманистички модел ангажује присутност антрополошких вредности на часу српског као завичајног - емоције, радозналост, инвенцију, алтруизам, емпатију, пријатељство, индивидуалност, социјална обележја, природно окружење;

- $\quad$ интегративни модел заснован је на повезивању разних културолошких садржаја унутар наставног подручја српски језик као завичајног - лингвистика унутар занимљивих и разноврсних тематских оквира из области националне културе (културне историје Срба, географског положаја Србије, знамења националног идентитета, познатих и у свету признатих Срба, научних домета и уметничких стварења из области књижевности, музике, сликарства, филма, театра, спорта, религије, народне традиције и фолклора);

- $\quad$ интеркултурални модел - повезивање српске са културом државе у којој ученик живи;

- $\quad$ стваралачки модел - ученик је активни језички стваралац на часу јер се подстиче на разноврсне говорне активности о различитим културолошким садржајима.

У наставној ситуацији када ученик недовољно познаје српски језик (ниво А1), наставник мора бити толерантан према његовим граматичким грешкама и подстицати његове комуникативне способности. Такође, дозвољена је употреба и других језика у циљу споразумевања између наставника ученика што се назива трансјезич-

\footnotetext{
${ }^{14} \mathrm{O}$ комуникативној методи видети више у истоименом поглављау монографије Методички хоризонти (Јањић 2017).
} 
ношћу. ${ }^{15}$ Трансференција је појава интерполације елемената једног језика у реченице другог језика и веома је изражена у говору српске дијаспоре. ${ }^{16}$ Веома је важно помагати ученицима да временом превазиђу овакав деструктиван начин изражавања. Временом, како буде овладавао граматичким системом српског језика, ученик ће све спретније и фреквентије формирати реченице на српском језику па ће се са трансјезичности комуникација полако усмеравати ка правилној употреби српског језика. Сукцесивно с тим ће и граматичка знања бити стабилнија и применљивија, ученик ће овладавати граматичком теоријом, дефиницијама и правилима. Значи, прво правило гласи (ниво А1 и А2): језичка функционалност изнад граматичке нормативности, комуникација испред граматичке теорије! Са унапређењем језичких компетенција (ниво Б1 и Б2) ученик ће се подробније упознати са граматичким системима српског језика и њоме потпуно овладати на нивоу Ц1 и Ц2. Ове препоруке долазе на основу примера добре наставне праксе наших суседа:

„Само такав слијед: потицање језичних дјелатности, развој понајприје комуникацијске, а тек потом и нешто касније лингвистичке компетенције, омогућит ће остварај координиране вишејезичности те реализацију сврховитога и учинковитога, а ипак ученицима примјеренога и занимљивога процеса овладавања хрватским језиком у хрватској настави у иноземству" (Павличевић-Франић 2012: 187).

\section{Закључак}

Због социокултурних и социолингвистичких специфичности у којима се одвија настава српског језика у дијаспори, неопходно је овом наставном процесу приступити зналачки и промишљено. Најпре, ова настава је специјална методичка грана наставе страног, а не матерњег језика и темељи се на развоју језичких компетенција и језичких вештина у области српског језика. Предност се даје најпре комуникацијској, а тек потом и граматичкој компетенцији јер се као циљ поставља употребно језичко знање у комуникативним ситуацијама па ваља применити принцип: прагматичност пре нормативности. Комуникативне комептенције ће својим развојем олакшати ученику усвајање граматичких правила тиме што ће постати база за усвајање свих граматичких (под)система српског језика, вокабуларала и његових изражајних потенцијала. Разноврсни тематски оквир из свих области српске националне културе учиниће наставу српског као завичајаног живописном, разноврсном и национонално аутентичном.

Функционалан, подстицајан и успешан наставни процес на часовима српског као завичајног посебно подразумева наставников труд, ученички индивидуални рад код куће, употребу изабраних наставних материјала и уџбеника, а изнад свега љубав према српском језику и српскоме роду.

\footnotetext{
${ }^{15}$ Нпр. ако је ученику матерњи језик фински, а српски и енглески не зна понајбоље, може се са наставником споразумевати комбинацијом српског и енглеског језика како би се одвијала комуникација на часу.

${ }^{16}$ Трансференција се најпре јавља у говору, а потом и у писму, и одвија се у правцу од доминантног језика ка подређеном (у овом случају из матерњег језика у завичајни). Трансференција је најчешће лексичка, али може бити и фонетска, граматичка, синтаксичка.
} 


\section{Литература}

Бобић М., Весковић Анђелковић М. „Профил и ставови потенцијалних миграната из Србије.” Гласник Етнографског института САНУ, LXIV/3: Истражсивање миграчија (2016): стр. 469-491.

Вучина Симовић И., Јовановић А. „Истраженост српског језика у дијаспори у оквирима филологије и лингвистичких дисциплина." Гласник Етнографског института САНУ, LXIV/3: Истраживање миграиија (2016): стр. 569-584.

Јањић М. „Комуникативна метода у разредној настави српског језика.” Учитељ, Београд, година XXXI, бр. 3 (2013): 379-388.

Јањић М., Чутура И. Простор, време, друштво - сусрети у језику. Јагодина: Педагошки факултет у Јагодини, 2012.

Јањић М. Методичке рефлексије о савременим аспектима наставе фонетике и фонологије српског језика. Ниш: Филозофски факултет, $2015 \mathrm{a}$.

Јањић М. Српски језик за ученике у дијаспори. Ниш: ОЦД Проактив, $2015 б$.

Јањић М. „Утицај прагмалингвистике на токове савремене наставе језика - од граматичких до говорних компетенција." Српски језик, XXI (2016): стр. 231-244.

Јањић М. Методички хоризонти - одабрана поглавља методике наставе српског језика и књижевности. Београд: NM libris, 2017.

Bloon E., Polinsky M. From Silence to Voice: Empowering Heritage Language Speakers in the 21st Century. Informes del Observatorio / Observatorio's Repor, 2015: 1-27. http://cervantesobservatorio.fas.harvard.edu/sites/default/files/007_informes_mp_ fromsilence_0.pdf

Cvikić L., Jelaska Z., Kanajet Šimić L. „Nasljedni govornici i njihova motivacija za učenje hrvatskoga jezika." Časopis za hrvatske studije, vol: 6, 113-127. https://hrcak.srce. $\mathrm{hr} / 86321$

Crvenkovska E. „Vtor, stranski, nasleden jazik: makedonsko-hrvatski paraleli.” Zbornik vo čest na prof. Minova-Đurkova po povod 70 godini od rađanjeto. Skoplje: Filološki fakultet „Blaže Koneski”, 2009: 69-79.

Cummins J. „A Proposal for Action: Strategies for Recognizing Heritage Language Competence as a Learning Resource within the Mainstream Classroom." The Modern Language Journal, Vol. 89, No. 4 (2005): pp. 585-592.

Feuerverger G. „University Students’ Perception of Heritage Language Learning and Ethnic Identity Maintenance." Canadian Modern Language Review, 47 (1991): p. 660-677.

Fishman J. „300-plus years of heritage language education in the United States.” Peyton, J. K., Ranard, D. A., McGinnis, S. (Eds.). Heritage languages in America: Preserving a national resource. Washington, DC \& McHenry, IL: Center for Applied Linguistics \& Delta Systems, 2001: 81-89.

Hržica G. „Kada je hrvatski pretežak i hrvatima: metodologija nastave hrvatskoga kao drugog jezika." Govor, XXIII/2 (2006): 163-179. https://hrcak.srce.hr/173653 
Jelaska Z. „Ovladavanje jezikom: izvornojezična i inojezična istraživanja.” Lahor, časopis za hrvatski kao materinski, drugi, strani jezik, god. I, br. 3 (2007): str. 86-99.

Jelaska Z. „Kategorija nasljednoga govornika: središte i granice.” ROMANOSLAVICA, Vol. LII, nr. 2 (2015): str. 171-187.

Kanrga M. „O zavičaju.” Delo, 1 (1972).

Kovačević M. „Zavičajni etnos i globalizacija.” Zavičajnost, globalizacija, škola. Gospić, 2006.

Marinović M. „Interkulturalni pristup nastavi povijesti.” Zavičajna povijest u interkulturalnom kontekstu. Zagreb: FF Zagreb, 2006.

Milošević Đorđević J. „Jedan pokušaj klasifikacije teorijskih razmatranja nacionalnog identiteta." Psihologija, vol. 36/2 (2003): str. 125-140.

Pavličević-Franić D. Komunikacijom do gramatike. Zagreb: Alfa, 2005.

Pavličević-Franić D. Jezikopisnice, rasprave o usvajanju, učenju i poučavanju hrvatskoga jezika u ranojezičnome diskursu. Biblioteka Scientia et Artes. Zagreb: Alfa, 2011.

Pavličević-Franić D. „Inojezično usvajanje hrvatskog kao nasljednoga jezika u hrvatskoj nastavi u inozemstvu." Hrvatska nastava u inozemstvu. Zagreb: Ministarstvo znanosti, obrazovanja i sporta - Učiteljski fakultet Sveučilišta u Zagrebu, 2012: str.181-187.

Pavličević-Franić D., Gazdić-Alerić T., Aladrović Slovaček K. „Jezične kompetencije učenika u hrvatskoj nastavi u inozemstvu." Napredak, časopis za pedagogijsku teoriju i praksu, vol. 153, br. 2, 2012.

Peruško T. Nastava o zavičaju (Istra). Skripta Pedagoške akademije - Pula, 1966.

Peyton J. K., Ranard D. A., McGinnis, S. (ur.). Heritage languages in America: Preserving a national resource. McHenry, IL: Delta Systems, 2001.

Podboj M. „Nasljedni jezik i nasljedni govornik.” Volumul cuprinde comunicări prezentate la Simpozionul internațional „Zilele culturilor slave în România”, București, 2-3 octombrie 2015. Romanoslavica, vol. LII, nr. 2 (2016).

Polinsky M., Kagan O. „Heritage Languages: In the 'Wild' and in the Classroom.” Language and Linguistics Compass, 1/5 (2007): 368-395.

Polinsky M. „Gender under incomplete acquisition: Heritage speakers' knowledge of noun categorization." Heritage Language Journal, 6/1 (2008).

Rosandić D. „Zavičajna povijest: pojmovni izazovi.” Zavičajna povijest u interkulturalnom kontekstu. Zagreb: FF, 2006.

Skok P. „Princip zavičajnosti u nastavni književnosti u osnovnoj školi.” Zavičajna književnost u nastavi. Žminj: Čakavski sabor, 1975.

Urošević N., Urošević-Hušak J. „Tematske rute u zavičajnoj nastavi - istarski književni inventari." Metodički obzori 7/3 (2012).

https://bib.irb.hr/datoteka/872877.Podboj_Nasljedni_jezik_i_identitet_Romanoslavica_52.2.pdf

https://bib.irb.hr/datoteka/872877.Podboj_Nasljedni_jezik_i_identitet_Romanoslavica_ 52.2.pdf

file://C:/Users/Marina/Downloads/Microsoft_Word_011_H_Tematske_rute_u_zavi_ ajnoj_nastavi_korekcija_NU_1.pdf 


\author{
Марина С. Янич \\ ФУНДАМЕНТАЛЬНЫЕ МЕТОДОЛОГИЧЕСКИЕ ВОПРОСЫ ОБУЧЕНИЯ СЕРБСКОМУ ЯЗЫКУ \\ В ЗАГРАНИЧЬЕ
}

Резюме

Предметом настоящей статьи являются методологические постановки обучения сербскому - родному языку в заграничье. В сути этого лингво-методического подхода находится принцип родного края в рамках национального идентитета, утвержденный представлениями родной педагогики. Занятия с учениками сербского языка в заграничье характеризуются особенностями, обоснованными: коммуникативной, понятийно-функциональной, интегративной, межкультуральной и творческой моделью обучения сербскому языку. Целью этого процесса является развитие лингвистической компетенции, т. е. языковых способностей учеников родного сербского языка.

Ключевые слова: диаспора, идентитет, национальность, родина, лингвометодика, языковая компетенция, коммуникация, интеркультуральность, трансференция. 